\title{
A new expansive two-open-doors laminoplasty for multilevel cervical spondylotic myelopathy: technical report and follow-up results
}

\author{
Nova técnica de laminoplastia expansiva para tratamento de mielopatia espondilotica \\ cervical: descrição técnica e resultados de follow-up
}

Aluizio Augusto Arantes Júnior ${ }^{1}$, Geraldo Alves da Silva Junior ${ }^{1}$, José Augusto Malheiros ${ }^{1}$, Fernando Flavio Gonçalves, Marcelo Magaldi', Erica Santiago², Arthur Adolfo Nicolato², Sebastião Nataniel Silva Gusmão?

\begin{abstract}
:
The laminoplasty technique was devised by Hirabayashi in 1978 for patients diagnosed with multilevel cervical spondylotic myelopathy. Objective: To describe an easy modification of Hirabayashi's method and present the clinical and radiological results from a five-year followup study. Method and Results: Eighty patients had 5 levels of decompression (C3-C7), 3 patients had 6 levels of decompression (C2-T1) and 3 patients had 4 levels of decompression (C3-C6). Foraminotomies were performed in 23 cases (27\%). Following Nurick`s scale, 76 patients (88\%) improved, 9 (11\%) had the same Nurick grade, and one patient worsened and was advised to undergo another surgical procedure. No deaths were observed. The mean surgery time was $122 \mathrm{~min}$. Radiographic evaluation showed an increase in the mean sagittal diameter from $11.2 \mathrm{~mm}$ at pretreatment to $17.3 \mathrm{~mm}$ post surgery. There was no significant difference between pretreatment and post-surgery C2-C7 angles. Conclusions: This two-open-doors laminoplasty technique is safe, easy and effective and can be used as an alternative treatment for cases of multilevel cervical spondylotic myelopathy without instability.
\end{abstract}

Keywords: laminoplasty, cervical spondylotic myelopathy, ossification of the posterior longitudinal ligament.

RESUMO:

A laminoplastia é técnica clássica descrita por Hirabayashi em 1978 para descompressão do canal cervical sem utilizar prótese. A principal indicação é o tratamento da mielopatia espondilotica cervical sem instabilidade. Objetivo: Descrever modificação simples da técnica de laminoplastia clássica de Hirabayashi com resultados clínicos e radiográficos em 5 anos de acompanhamento. Resultados e Método: Foram acompanhados 86 pacientes. Em 80, foi feita descompressão por laminoplastia em 5 níveis (C3-C7); em 3, descompressão em 6 níveis (C2-T1); em 3, descompressao em 4 níveis (C3-C6). Em 23 casos (27\%), foi realizada foraminotomia associada a descompressão medular. 0 acompanhamento dos pacientes foi feito utilizando a escala de Nurick. Em 76 pacientes (88\%) houve melhora do grau de Nurick. Não houve mortalidade associada à técnica. 0 tempo médio do procedimento cirúrgico foi de 122 minutos. Em relação à avaliação radiográfica, houve aumento do diâmetro sagital médio do canal cervical de 11,2mm para 17,3mm. Não houve diferença estatística do ângulo C2-C7 nas avaliações antes e após o procedimento cirúrgico. Conclusão: A nova técnica de laminoplastia descrita no presente estudo foi segura, de fácil execução, efetiva, não utiliza protese e não há instabilidade do canal cervical.

Palavras-chave: laminoplastia, mielopatia espondilotica cervical, ossificação do ligamento longitudional posterior.

Cervical degenerative myelopathy is a common condition affecting $2 \%$ of all hospital admissions according to a number of studies ${ }^{1,2}$. The two main causes of this condition are cervical spondylosis and ossification of the posterior longitudinal ligament (OPLL) ${ }^{3}$. Such conditions progress with age and can eventually result in the impairment of multilevel segments and multilevel cervical spondylotic myelopathy (MCSM).

\footnotetext{
'Department of Neurosurgery, Clinical Hospital of the Federal University of Minas Gerais, Belo Horizonte MG, Brazil;

${ }^{2}$ Federal University of Minas Gerais - School of Medicine, Belo Horizonte MG, Brazil;

${ }^{3}$ Orthopedist at Madre Tereza Hospital, Belo Horizonte MG, Brazil.

Correspondence: Aluizio Augusto Arantes Junior; Rua dos Inconfidentes 320/801; 30140-120 Belo Horizonte MG - Brasil; E-mail:aluizio_arantes@uol.com.br Conflict of interest: There are no conflicts of interest to declare.

Received 27 August 2012; Received in final form 26 October 2013; Accepted 04 November 2013.
} 
There are numerous surgical strategies for MCSM, and controversies have arisen between researchers regarding the use of an anterior or posterior approach, prophylactic surgery, and conservative (non-surgical) versus surgical treatment.

This paper describes a new technique for cervical laminoplasties with a minimum of 5 years of follow-up in 86 patients.

\section{Series}

We prospectively analyzed patients undergoing laminoplasties from March 2001 to March 2006 in the Hospital das Clinicas of the Federal University of Minas Gerais and the Hospital Madre Tereza, Belo Horizonte, Brazil. These patients were followed for at least 5 years with both clinical and radiographic evaluations.

\section{METHODS}

All of the patients (from the Hospital das Clinicas and the Hospital Madre Tereza) who were exhibiting clinical evidence of myelopathy, with or without radiculopathy, underwent complete radiographic evaluation.

Radiographic evaluation consisted of neutral anteriorposterior (AP) imaging, conventional x-ray imaging, lateral imaging, flexion/extension $\mathrm{x}$-ray imaging, computed tomography (CT) and magnetic resonance imaging (MRI).

Patients with MCSM and radiographic signs of instability ${ }^{4,5}$ or deformity were excluded and directed towards another surgical strategy. We considered cases of cervical instability with any antero-posterior deviation $>3 \mathrm{~mm}$, a relative translation of a vertebra in a sagittal plane $>3.5 \mathrm{~mm}$, or angulation of one vertebra to another $>11^{\circ}$.

The patients with cervical multilevel stenosis (cervical spine canal diameter $<12 \mathrm{~mm}$ ) without instability or even with some clinical impairment, such as those of grade 2 or 3 according to the physical status classification system of the American Society of Anesthesiologists (ASA), were enrolled in this study.

The Nurick scale ${ }^{6}$ was used to clinically evaluate and objectively compare the preoperative data and the postoperative follow-up data.

Follow-up was conducted over a minimum of five years and consisted of both clinical and radiographic evaluations. Postoperative follow-up data were recorded at 1, 3, 6, 12, 18, 24, 36, 48 and 60 months.

An independent examiner carried out the preoperative assessment and recorded the results.

This study was approved by the ethics board of the Federal University of Minas Gerais.

\section{Technical report}

After a longitudinal median incision and a subperiosteal dissection, the cervical spine is exposed, as well as the laminae and spinous processes. Care must be taken taken to preserve the paraspinal muscles where they join the spinous process of $\mathrm{C} 2$.

The next step is to decide how to perform the arthrodesis and on which side the laminae will be opened. This decision is made individually according to both clinical and radiological findings in the preoperative evaluation. The procedure allows an alternated foraminotomy (alternated at successive levels) for radicular decompression.

The interspinous, interlaminar and yellow ligaments must be cut between vertebrae $\mathrm{C} 2$ and $\mathrm{C} 3, \mathrm{C} 7$ and $\mathrm{T} 1$ and $\mathrm{C} 4$ and C5, respectively, to construct two blocks of laminae. Inside each block, the yellow ligament must be preserved.

To create the opening for the laminae, a high-speed drill and a $2 \mathrm{~mm}$ Kerrison rongeur are used to cut a complete path through the lateral part of the laminae on one side of $\mathrm{C} 3-\mathrm{C} 4$ and another complete path through C5-C6 on the opposite side. The external cortical bone layers of both closed sides must also be drilled, creating a greenstick fracture and opening the doors (Figures 1 and 2). This technique allows C5 foraminotomy on both sides.

Instead of one open door, as described by Hirabayashi, the goal of this procedure is to obtain two open doors that will be united in the middle (between $\mathrm{C} 4$ and $\mathrm{C5}$ ) by sutures. Therefore, two doors and three arthrodesis points are constructed at C4-C5 and at both lateral parts of the laminae (on opposite sides).

Depending on the clinical and radiographic findings, the decompression can be extended to include $\mathrm{C} 7$ or $\mathrm{C} 2$ by partial laminectomy.

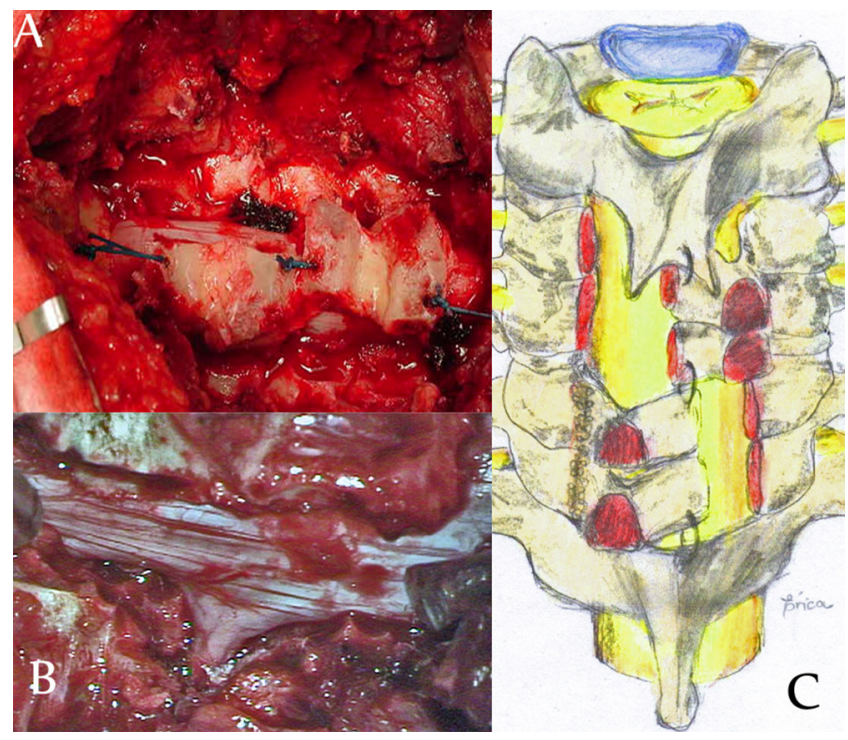

Figure 1. A) surgical view of the two parts of the construction united by simple sutures; B) surgical view of the cervical root C5 after decompression; C) illustration of the final aspect of a laminoplasty at C3-C6. There are three arthrodesis areas, two of which are lateral and one of which is in the midline between C4 and C5. 


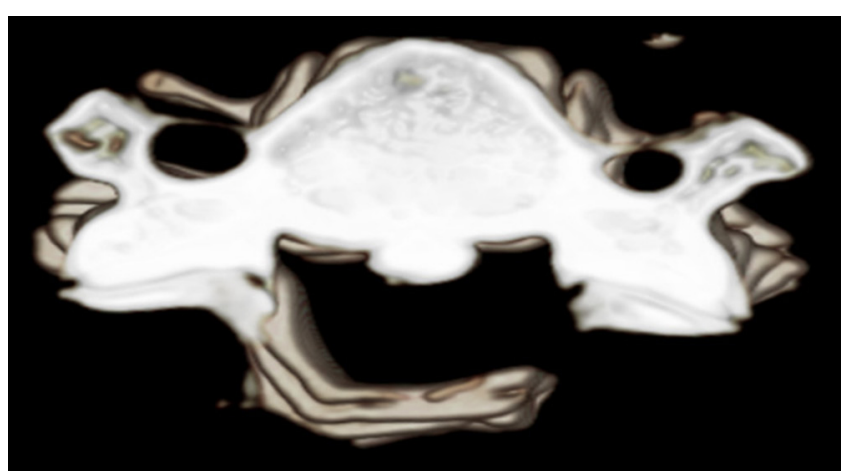

Figure 2. Three-dimensional CT scan showing a greenstick fracture (right) after the opening of the lamina on the left side.

The blocks are held by sutures between the $\mathrm{C} 2$ spinous process and the $\mathrm{C} 3$ lamina, between the $\mathrm{C} 4$ and $\mathrm{C} 5$ laminae, and between the $\mathrm{C} 6$ lamina and $\mathrm{C} 7$ spinous process. The first and most important suture is between $\mathrm{C} 4$ and $\mathrm{C} 5$. This suture lines the extremities of both laminae (C4-C5) such that arthrodesis can be performed in the center and middle of the construction. A bone graft is taken from the spinous process and inserted into the excavation created in the lateral part of the laminae (Figure 1).

During postoperative recuperation, muscle relaxants are administered and a Philadelphia cervical collar is used for 30 days in order to provide immobilization and comfort for the patient. After one month, the patients are driven to physiotherapy for the purpose of cervical muscle rehabilitation.

\section{RESULTS}

From March 2001 to March 2006, 86 patients underwent laminoplasties. Of these patients, 64 were male (74\%), and 22 were female (26\%). The mean age was 63 years.

In 80 patients (92\%), the laminoplasties were performed between vertebrae $\mathrm{C} 3$ and $\mathrm{C}$; in 3 patients (4\%), they were performed between $\mathrm{C} 2$ and $\mathrm{C} 6$; and in 3 patients (4\%) they were performed between $\mathrm{C} 2$ and $\mathrm{T} 1$. Foraminotomies were performed in 23 cases (27\%).

Following the Nurick scale, 76 patients (88\%) improved, 9 (11\%) had the same Nurick grade, and one patient worsened and was scheduled for another surgical procedure. No deaths were observed (Tables 1 and 2).

The mean surgery time was $122 \mathrm{~min}$. Radiographic evaluation showed an increase in the mean sagittal diameter from $11.2 \mathrm{~mm}$ pretreatment to $17.3 \mathrm{~mm}$ post surgery (Table 3). There was no significant difference between the $\mathrm{C} 2-\mathrm{C} 7$ angle before treatment and post surgery. No cases of kyphosis or progressive spine instability were observed (Table 4).
Table 1. Results following surgery, based on the Nurick scale.

\begin{tabular}{lcccccc}
\multirow{2}{*}{ Nurick grade } & \multicolumn{2}{c}{ Before surgery } & & \multicolumn{2}{c}{ After surgery } \\
\cline { 2 - 3 } \cline { 5 - 7 } & $\mathrm{n}$ & $\%$ & & $\mathrm{n}$ & $\%$ \\
\hline 0 & 4 & 4.7 & & 6 & 7.0 \\
1 & 2 & 2.3 & & 14 & 16.3 \\
2 & 0 & 0.0 & & 58 & 67.4 \\
3 & 5 & 5.8 & & 7 & 8.1 \\
4 & 57 & 66.3 & & 1 & 1.2 \\
5 & 18 & 20.9 & & 0 & 0.0 \\
\hline Median & \multicolumn{3}{c}{4} & & \multicolumn{3}{c}{2}
\end{tabular}

Pvalue for marginal homogeneity test $<0.001$.

Table 2. Results based on improvement after surgery.

\begin{tabular}{lcc}
\hline Results & $\mathrm{n}$ & $\%$ \\
\hline Improvement* & 76 & 88 \\
1 grade & 7 & 8 \\
2 or more grades & 89 & 80 \\
O grades (the same grade as preoperatively) & 9 & 11 \\
Worse & 1 & 1 \\
Death & 0 & 0 \\
\hline
\end{tabular}

*Based on the Nurick scale

Table 3. Comparison between the sagittal diameter before and after laminoplasty $(n=86)$.

\begin{tabular}{lcc}
\hline Sagittal diameter & Before surgery $(\mathrm{mm})$ & After surgery $(\mathrm{mm})$ \\
\hline Mean & 13.3 & 19.4 \\
Median & 13.0 & 19.0 \\
Standard deviation & 3.4 & 3.2 \\
Minimum & 7.0 & 14.0 \\
Maximum & 22.0 & 30.0 \\
\hline * -value for the Wilcoxon signed rank test $<0.001$ &
\end{tabular}

${ }^{*} \mathrm{p}$-value for the Wilcoxon signed rank test $<0.001$.

Table 4. C2-C7 angle comparison: before and after laminoplasty $(\mathrm{n}=86)$.

\begin{tabular}{lcc}
\hline C2-C7 angle & Before surgery & After surgery \\
\hline Mean & 17.5 & 17.9 \\
Median & 20.0 & 20.0 \\
Standard deviation & 6.7 & 6.4 \\
Minimum & 5.0 & 5.0 \\
Maximum & 36.0 & 35.0 \\
\hline
\end{tabular}

${ }^{*} \mathrm{p}$-value for the Wilcoxon signed rank test $=0.002$.

Thirty days post surgery (with good outcomes after treatment with analgesics and anti-inflammatory drugs), cervicalgia was reported in 8 patients (9\%). One patient required reoperation because of a local hematoma. Another patient required reoperation after clinical worsening caused by fracture and migration of the lamina on one side of the laminoplasty. Two patients exhibited C5 radiculopathy after surgery and spontaneous recovery after six months (Table 5). 
Table 5. Postoperative complications.

\begin{tabular}{lcc} 
Complication & $\mathrm{n}$ & $\%$ \\
\hline Cervicalgia & 8 & 9 \\
Reoperation & 2 & 2 \\
Hematoma & 1 & 1 \\
Neurological worsening & 1 & 1 \\
C5 radiculopathy & 2 & 2 \\
\hline
\end{tabular}

\section{DISCUSSION}

There are numerous surgical strategies for treating multilevel cervical spondylotic myelopathy (MCSM), and there is no standard procedure. Controversies over the superiority of anterior or posterior approaches remain, and no consensus has been reached. The laminoplasty is one option among the wide range of posterior approaches.

The anterior approach is performed by multilevel cervical discectomy with or without corpectomy and fusion. The main advantage of this approach is the possibility of direct spinal decompression through the removal of osteophytes, extruded discs, or thin longitudinal ligaments. This technique is safe for up to three segments ${ }^{7}$, after which negative results, such as pseudoarthrosis, graft migration and instrumentation failure ${ }^{8,9}$, occur.

The classic posterior approach for MCSM is the laminectomy. Despite impressive decompression results, this technique has been associated with post-surgery spine instability and kyphosis ${ }^{11}$, post-surgery compression by fibrous tissue, and diminished clinical results ${ }^{12}$.

The laminoplasty technique is a variant of the laminectomy, which was first described by Hirabayashi ${ }^{13}$ in 1978 with the purpose of decompressing the spine and reducing the complications resulting from the classic laminectomy. Multiple variations on the technique have been created, but all of these methods share the same idea of cervical expansion with a protective dorsal element ${ }^{14,15}$.

Wada et al. ${ }^{16}$ comparatively analyzed the corpectomy and the laminoplasty as treatments for MCSM. There was no difference in the functional outcomes of these groups, but pseudoarthrosis was reported in $26 \%$ of the patients in the corpectomy group. Herkowitz ${ }^{17}$ compared anterior fusion with laminectomies and laminoplasties in 45 patients with 2 years of followup. Excellent to good results were reported for $92 \%$ of patients in the anterior group compared with $86 \%$ in the laminoplasty group and $66 \%$ in the laminectomy group. No significant difference in outcomes was found between the anterior fusion and laminoplasty groups, but pseudoarthrosis was reported in $37 \%$ of the patients in the anterior fusion group. These results are consistent with other published series ${ }^{18,19}$.

Another option is to combine the laminectomy and the posterior cervical fusion in order to avoid kyphosis related to the loss of the posterior column resulting from the laminectomy.
Heller et al..$^{20}$ analyzed patients undergoing laminectomies and instrumented posterior fusion with laminoplasties, and they observed no differences in functional outcomes, although a greater number of complications were found in the laminectomy group.

A review of the literature reveals no difference in the functional outcomes of the laminoplasty variants ${ }^{21-24}$. Conversely, a great number of these variants are technically difficult to perform, while others are cumbersome in their use of bone grafting and require a prohibitive number of suture points. Other disadvantages in certain types of laminoplasties result from the required use of instrumentation to maintain the open door and from the fact that the foraminotomy is possible on only one side.

Our results were descriptive but not comparative. Therefore, our main goal was to describe our technique and not compare the different kinds of technique available in the literature.

In order to avoid these shortcomings, we have proposed an easier laminoplasty technique involving just three suture points, requiring no instrumentation to maintain the open door, and making foraminal decompression possible on both sides. Using this procedure, the door remained opened throughout the five years of follow-up on account of three arthrodesis points that were created: two lateral points (one on either side of the construction) and one point in the middle of the construction. This technique increased the median sagittal diameter from $11.2 \mathrm{~mm}$ to $17.3 \mathrm{~mm}$. Compared with other series ${ }^{21-24}$, our technique caused the greatest expansion in the medium sagittal diameter, as determined by radiographic evaluation (Figure 3). Other published series have reported similar results: Wang et al. ${ }^{3}$ reported an increase from $9.8 \mathrm{~mm}$ to $16.6 \mathrm{~mm}$; O ${ }^{`}$ Brien et al. ${ }^{23}$ reported an increase from $8.2 \mathrm{~mm}$ to $16.6 \mathrm{~mm}$; and Satomi et al. ${ }^{24}$ reported an increase from $12.0 \mathrm{~mm}$ to $15.7 \mathrm{~mm}$.

Kyphotic sagittal alignments reportedly developed in $0-10 \%$ of patients after laminoplasty, depending on the series $^{25-30}$. Iwasaki et al. ${ }^{26}$ reported a deterioration of cervical lordosis into kyphosis in 5 patients (8\%) of 59 without neurological sequelae. The present study revealed no significant change in the $\mathrm{C} 2-\mathrm{C} 7$ angle measured before treatment and three years post surgery, and there was no evidence of postsurgery progressive kyphosis.

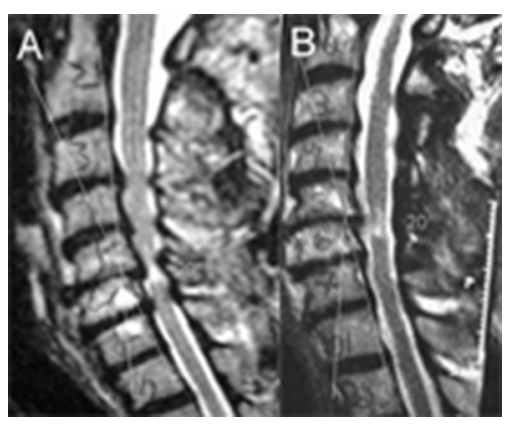

Figure 3. Sagittal IRM showing preoperative (A) and postoperative (B) status. 
Another complication relating to the laminoplasty technique is the observance of C5 radiculopathy, which probably results from traction on the nerve, as the cord migrates dorsally after decompression. In published studies, this particular complication rate varies from $5 \%$ to $14 \%^{22-25}$. Sasai et al. ${ }^{25}$ discussed the role of prophylactic foraminotomies in decreasing the incidence of motor palsy after laminoplasties. Lee et al. ${ }^{1}$ performed concomitant foraminotomies in 11 of 105 patients undergoing open-door laminoplasties and reported improvements in 10 of 11 patients (91\%). In our study, we had two cases of C5 radiculopathy (2\%), but these cases exhibited spontaneous recovery. We attributed the low rate of complications observed in our series to the bilateral foraminotomy, which was made possible at this level by our technique of two-open-doors laminoplasty.

Another important advantage of our technique is that it exhibits the shortest surgery time compared with other techniques. This advantage allows the surgical procedure to be performed in older patients with high-grade ASA (anterior spinal artery) conditions. Our series revealed a low rate of general clinical complications, even for the patient group with a median age of 63 years.

The literature reports an overall recovery rate after laminoplasties ranging from $50 \%$ to $70 \%^{1,3,26,27}$. The positive outcome factors reported include the patient's age, the time of symptomatic myelopathy, and the degree of spinal compression as determined by radiographic evaluation. Our series demonstrates a clinical improvement of $88 \%$.

Compared with the anterior approach, the incidence of axial neck pain and muscle atrophy is greater after laminoplasty surgery. In a meta-analysis of 71 retrospective papers, Sani et al..$^{29}$ found an overall rate of axial neck pain that varied from $6 \%$ to $60 \%$. In our study, axial neck pain was observed in 8 patients (9\%). Except for one patient who had persistent axial neck pain, all of these patients fully recovered after 3 months of physical therapy. We believe that this result is due to the surgical technique of dissection and de-insertion of the muscles that attach to the $\mathrm{C} 2$ spinous process. Matsunaga et al. ${ }^{10}$ demonstrated that a post-surgery loss of sagittal alignment was strongly associated with dissection and the subsequent nonhealing of the muscle insertion at C2. In our technique, all of the attachments of the C2 spinous process are preserved.

Finally, laminoplasties cannot be used in kyphotic cervical spines, owing to the risk of post-surgery complications and instability $1,3,5,26,27$.

\section{CONCLUSIONS}

The two-open-doors laminoplasty technique used in this study demonstrates a safe, easy and effective surgical procedure and provides an alternative for cases of multilevel cervical spondylotic myelopathy without deformation. This method is associated with a low rate of complications, a short operating time, and no incidence of post-surgery kyphosis or late instability. Furthermore, the two-open-doors laminoplasty technique does not require a heterologous graft or instrumentation. Therefore, this technique may represent a useful option for geriatric patients.

\section{References}

1. Lee TT, Green BA, Gromelski EB. Safety and stability of open-door cervical expansive laminoplasty.J Spinal Disord 1998;11:12-15.

2. Tomita K, Kawahara N, Toribatake Y, Heller JG. Expansive midline T-saw laminoplasty (modified spinous process-splitting) for the management of cervical myelopathy. Spine 1998;23:32-37.

3. Wang MC, Kreuter W, Wolfla CE, et al. Trends and variations in cervical spine surgery in the United States: Medicare beneficiaries, 1992 to 2005. Spine 2009;34:955-961.

4. Lam FC, Irwin BJ, Poskitt KJ, Steinbok P. Cervical spine instability following cervical laminectomies for Chiari II malformation: a retrospective cohort study. Childs Nerv Syst 2009;25:71-76.

5. White AA 3rd, Johnson RM, Panjabi MM, Southwick WO. Biomechanical analysis of clinical stability in the cervical spine. Clin Orthop 1975;109:85-96.

6. Nurick S. The pathogenesis of the spinal cord disorder associated with cervical spondylosis. Brain 1972;95:87-100.

7. Arantes A, Gusmão S, Rubinstein F, Oliveira R. Microsurgical anatomy of the recurrent laryngeal nerve: applications on the anterior approach to the cervical spine. Arq Neuropsiquiatr 2004;62:707-710.

8. Edwards, C, Heller, J, Morikami, H, et al. Corpectomy versus laminoplasty for multi-level cervical myelopathy: An independent matched cohort study. Spine 2002;27:1168-1175.
Vaccaro, AR, Falatyn, SP, Scuderi, GJ, et al. Early failure of long segment anterior cervical plate fixation. J Spinal Disord 1998;11:410-415.

10. Matsunaga, S, Sakou, T, Nakansisi, K, et al. Analysis of the cervical spine alignment following laminoplasty and laminectomy. Spinal Cord 1999;37:20-24

11. Yonenobu, K, Okada, K, Fuji, T, Fujiwara, K, Yamashita, K, Ono, K. Causes of neurologic deterioration following surgical treatment of cervical myelopathy. Spine 1986;11:818-823.

12. Dai R, Ni B, Yuan W, Jia L. Radiculopathy after laminectomy for cervical compression myelopathy. J Bone Joint Surg Br 1998;80:846-84.

13. Hirabayashi K, Satomi K. Operative procedure and results of expansive open-door laminoplasty. Spine 1988;13:870-876.

14. Andrade GC, Silveira RL, Arantes A, Pinheiro N, Rocha EMM Laminoplastia expansiva. Arq Neuropsiquiatr 2005;63:1005-1009.

15. Steinmetz MP, Resnick DK. Cervical laminoplasty. Spine J 2006;6(Suppl):S274-S281.

16. Wada E, Suzukim S, Kanazawa A. Subtotal corpectomy versus laminoplasty for multilevel cervical spondylotic myelopathy: a longterm follow-up study over 10 years. Spine 2001;26:1443-1447.

17. Herkowitz HN. A comparison of anterior cervical fusion, cervical laminectomy and cervical laminoplasty for the surgical management of multiple level spondylotic radiculopathy. Spine 1988;13:774-780. 
18. Yonenobu K, Hosono N, Iwasaki M, et al. Laminoplasty versus subtotal corpectomy: a comparative study of results in multisegmental cervical spondylotic myelopathy. Spine 1992;17:1281-1284.

19. Edwards $\mathrm{C}$, Heller J, Morikami H, et al. Corpectomy versus laminoplasty for multi-level cervical myelopathy: An independent matched cohort study. Spine 2002;27:1168-1175.

20. Heller JG, Edwards CC 2nd, Murakami H, Rodts GE. Laminoplasty versus laminectomy and fusion for multilevel cervical myelopathy: an independent matched cohort analysis. Spine 2001;26:1330-1336.

21. Hirabayashi K, Watanabe K, Wakano K, et al. Expansive opendoor laminoplasty for cervical spinal stenotic myelopathy. Spine 1988;8:693-699.

22. Fan D, Schwartz D, Vaccaro A, Hilibrand A, Albert T. Intraoperative neurophysiologic detection of iatrogenic C5 nerve root injury during laminectomy for cervical compression myelopathy. Spine 2002;27:2499-2502.

23. O'Brien MF, Peterson D, Casey ATH, Crockard HA. A novel technique for laminoplasty augmentation of spinal canal area using titanium miniplate stabilization: a computerized morphometric analysis. Spine 1996;21:474-483.
24. Satomi K, Nishu Y, Kohno T, Hirabayashi K. Long-term follow-up studies of open-door expansive laminoplasty for cervical stenotic myelopathy. Spine 1994;19:507-510.

25. Sasai K, Saito T, Akagi S, et al. Preventing C5 palsy after laminoplasty. Spine 2003;28:1972-1977.

26. Iwasaki M, Kawaguchi Y, Kimura T, et al. Long-term results of expansive laminoplasty for ossification of the posterior longitudinal ligament of the cervical spine: more than 10 years follow-up. J Neurosurg 2002;96(Suppl):180-189.

27. Hale JJ, Gruson KI, Spivak JM. Laminoplasty: a review of its role in compressive cervical myelopathy. Spine $J$ 2006;6(Suppl):S289-S298.

28. Martin-Benlloch JA, Maruenda-Paulino JI, Barra-Pla A, LaguiaGarzaram M. Expansive laminoplasty as a method for managing cervical multilevel spondylotic myelopathy. Spine 2003;28:680-684.

29. Sani S, Ratliff JK, Cooper PR. A critical review of cervical laminoplasty. Neurosurg Q 2004;14:5-16.

30. Suda K, Abumi K, Ito M, et al. Local kyphosis reduces surgical outcomes of expansive open-door laminoplasty for cervical spondylotic myelopathy. Spine 2003;28:1258-1261. 